\title{
Helicobacter heilmannii sp. nov., isolated from feline gastric mucosa
}

2

3

4

5

6

7

8

9

10

11

12

13

14

15

16

17

18

19

20

21

22

23

24 1

${ }^{1}$ Department of Pathology, Bacteriology and Avian Diseases, Faculty of Veterinary Medicine, Ghent University, Salisburylaan 133, B-9820 Merelbeke, Belgium

$$
\text { F., }{ }^{1 \ominus} \text { Haesebrouck F. }{ }^{1 \Theta}
$$

Smet A., ${ }^{1 *}$ Flahou B., ${ }^{1}$ D’Herde K., ${ }^{2}$ Vandamme P., ${ }^{3}$ Cleenwerck I., ${ }^{3}$ Ducatelle R., ${ }^{1}$ Pasmans,

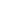
7 8

${ }^{2}$ Department of Basic Medical Sciences, Faculty of Medicine and Health Sciences, Ghent University, De Pintelaan 185, B-9000 Ghent, Belgium 1

${ }^{3}$ Department of Biochemistry and Microbiology, Faculty of Sciences, Ghent University, Ledeganckstraat 35, B-9000 Ghent, Belgium

* Corresponding author: Mailing address: Department of Pathology, Bacteriology and Avian Diseases, Ghent University, Faculty of Veterinary Medicine, Salisburylaan 133, B-9820 Merelbeke, Belgium;

8 Tel: +32-9-2647435; Fax: +32-9-2647494;

9 E-mail: Annemieke. Smet@UGent.be

\footnotetext{
${ }^{\ominus}$ Shared senior authorship
} 
Three Gram-negative, microaerophilic bacteria with a corkscrew-like morphology isolated from the gastric mucosa of cats and designated ASB1 ${ }^{\mathrm{T}}$, ASB2 and ASB3, were subjected to a polyphasic taxonomic study. The isolates grew on biphasic culture plates in microaerobic conditions at $37^{\circ} \mathrm{C}$ and exhibited urease, oxidase and catalase activity. They were also able to grow in colonies on dry agar plates. Based on $16 \mathrm{~S}$ rRNA gene sequence analysis, $\mathrm{ASB} 1^{\mathrm{T}}$, ASB2 and ASB3 were identified as members of the genus Helicobacter and showed 98 to 99\% sequence similarity to $H$. felis, $H$. bizzozeronii, "Candidatus H. heilmannii", $H$. cynogastricus, $H$. baculiformis and $H$. salomonis, six related Helicobacter species previously detected in the feline or canine gastric mucosa. Sequencing of the partial hsp60 gene demonstrated that ASB1 ${ }^{\mathrm{T}}$, ASB2 and ASB3 constitute a separate taxon among the feline and canine Helicobacter spp. The urease gene sequences of $\mathrm{ASB} 1^{\mathrm{T}}$, ASB2 and ASB3 showed approximately $91 \%$ similarity to the urease gene sequences of "Candidatus Helicobacter heilmannii". Protein profiling, the absence of alkaline phosphatase activity and several other biochemical characteristics also allowed to differentiate the strains ASB1 ${ }^{\mathrm{T}}$, ASB2 and ASB3 from other Helicobacter species of feline or canine gastric origin. The results of this polyphasic taxonomic study show that the cultured isolates constitute a new taxon corresponding to "Candidatus Helicobacter heilmannii" previously demonstrated in the stomach of humans, wild felidae, cats and dogs. The name Helicobacter heilmannii sp. nov. is proposed for these new isolates. 
Long, spiral-shaped bacteria belonging to the genus Helicobacter have been demonstrated in the gastric mucosa of man and several animal species (Haesebrouck et al., 2009). Helicobacter $(H$.$) pylori is the most common and best known gastric Helicobacter species in$ humans. Today, a large number of gastric non-Helicobacter pylori Helicobacter spp., provisionally named $H$. heilmannii and naturally colonizing the stomach of animals, have also been described in humans. Sequence analysis of 16S rRNA genes detected in 'Helicobacter heilmannii'-positive gastric biopsies revealed the presence of two sequence types. This has led to the sub classification of the non-Helicobacter pylori helicobacters into 'Helicobacter heilmannii' type 1 and 'Helicobacter heilmannii' type 2. H. heilmannii type 1 represents a single Helicobacter species, namely $H$. suis. ' $H$. heilmannii' type 2 represents a group of species, including $H$. felis, H. bizzozeronii, H. salomonis, and 'Candidatus $\mathrm{H}$. heilmannii'(Baele et al., 2008a; Haesebrouck et al., 2009).

The first Helicobacter species isolated from the stomach of cats and dogs was $H$. felis (Lee et al., 1988). Later on, H. bizzozeronii, H. salomonis, H. baculiformis and H. cynogastricus were also isolated from the feline and canine gastric mucosa (Baele et al., 2008b; Hänninen et al., 1996; Happonen et al., 1996; Jalava et al., 1998; Jalava et al., 2001; Van den Bulck et al., 2006). H. cynogastricus and H. baculiformis have not yet been detected in the human gastric mucosa. A sixth long spiral shaped Helicobacter sp. has been detected in wild feline and human, as well as in canine and feline gastric biopsies (Neiger et al., 1998; Hwang et al., 2002; O'Rourke et al., 2004b). It could not be cultured in vitro and was provisionally named 'Candidatus Helicobacter heilmannii' (O’ Rourke et al., 2004b). Based on 16S rRNA gene sequence analysis, all these species are phylogenetically highly related to each other (Solnick et al., 1993). The similarity of their ureAB urease genes is, however, lower than $85 \%$, allowing discrimination between these species (O'Rourke et al., 2004b). The uncultured "Candidatus Helicobacter heilmannii" was found with a prevalence ranging from $20 \%$ to 
$100 \%$ in the gastric mucosa of both cats and dogs (Haesebrouck et al., 2009; Hwang et al., 2002; Neiger et al., 1998; Van den Bulck et al., 2005). It was detected in 8-19\% of gastric biopsy samples of humans with histological evidence of a non-Helicobacter pylori Helicobacter infection (Haesebrouck et al., 2009; Trebesius et al., 2001; Van den Bulck et al., 2005). Moreover, "Candidatus Helicobacter heilmannii” has been propagated in mice for up to 28 months and was able to induce mucosa associated lymphoid tissue (MALT) lymphomas in the stomach of these animals (O'Rourke et al., 2004a).

In this study, we describe the successful isolation of "Candidatus Helicobacter heilmannii" in vitro and the characterisation of this species using a polyphasic taxonomic study.

The strain, designated ASB $1^{\mathrm{T}}$ (= type strain), was isolated from the mucosa of the stomach of a cat euthanized at a shelter for homeless cats, Sint-Niklaas, Belgium. The two other strains, designated ASB2 and ASB3, were isolated from the mucosa of the stomach of cats (positive for feline immunodeficiency virus) euthanized at the faculty of Veterinary Medicine, Ghent University, Belgium.

The stomachs of these 3 cats were submersed in a $1 \% \mathrm{HCl}$ bath for 1 hour (Gruntar et al., 2003). The mucus was scraped off using a glass slide, and collected in a sterile tube.

It was inoculated on Brucella agar plates supplemented with $20 \%$ (v/v) foetal calf serum, 5 mg/l amphotericin B (Fungizone; Brystal-Myers Squibb, New York, USA), Campylobacterselective supplement (Skirrow, Oxoid, Aalst, Belgium; containing $10 \mathrm{mg} / \mathrm{l}$ vancomycin, 5 $\mathrm{mg} / \mathrm{l}$ trimethoprim lactate and $2500 \mathrm{U} / 1$ polymyxin B), Vitox supplement (Oxoid), $0.1 \%$ activated charcoal and ca. $0.05 \% \mathrm{HCl}$ to obtain a $\mathrm{pH}$ of 5 . The mucus on these agar plates was slightly liquefied with Brucella broth containing $20 \%$ foetal calf serum. The plates were incubated at $37^{\circ} \mathrm{C}$ under microaerobic conditions with a gas mixture of $10 \% \mathrm{CO}_{2}, 5 \% \mathrm{O}_{2}$ and $85 \% \mathrm{~N}_{2}$. Plates were checked every day and Brucella broth (pH 5) supplemented with $20 \%$ 
foetal calf serum was added to the agar surface to ensure that the plates did not become dry.

100 Primary growth was examined by light microscopy, revealing the presence of large, spiral101 shaped and motile bacterial cells. Growth of subcultures occurred as a spreading layer on moist agar plates. Bacterial cells were harvested in Brucella broth and stored at $-70^{\circ} \mathrm{C}$ in a medium consisting of $7.5 \mathrm{~g}$ glucose, $25 \mathrm{ml}$ Brucella broth and $75 \mathrm{ml}$ sterile inactivated foetal

104 calf serum.

105

106 Genomic DNA of isolates ASB1 ${ }^{\mathrm{T}}$, ASB2 and ASB3 was extracted using PrepMan sample 107 preparation reagent from Applied Biosystems as described by the manufacturer. and primers $\alpha \beta$-NOT (5'-TCAAACTAGGACCGAGTC-3') and $\omega \mathrm{MB} \quad$ (5'TACCTTGTTACTTCACCCCA-3') as described by Baele et al., 2001. The PCR products

112 were sequenced using the BigDye Terminator sequencing kit (Applied Biosystems,

113 California, USA) and primers pD, Gamma ${ }^{*}, 3$ and O* (Coenye et al., 1999). Sequences were 114 determined on an automatic DNA sequencer (ABI Prism 3100 Genetic analyser; Applied 115 Biosystems) and the electropherograms were exported and converted to the VectorNTI 116 software (Invitrogen, Merelbeke, Belgium). The sequences were compared with the NCBI 117 genbank by using the BLAST search tool. All Helicobacter species with validly published 118 names (http://www.bacterio.cict.fr/h/helicobacter.html) were included for phylogenetic 119 analysis. Phylogenetic analysis was performed using the ClustalW, BioEdit and Jalview 120 software tools. Multiple alignment was determined using ClustalW with an open gap penalty 121 of $100 \%$ and a unit gap penalty of $0 \%$. A phylogenetic tree, with $H$. pylori as outgroup, was constructed using the neighbour-joining method and is shown in Fig. 1. The 16S rRNA gene

123 sequences of strains $\mathrm{ASB} 1^{\mathrm{T}}$, ASB2 and ASB3 showed more than $98 \%$ sequence similarity 
124 with each other (Genbank accession no. HM625820, HM625819, HM625818) and with a

125 sequence from Genbank, Genbank no. AF506786 (originating from 'Candidatus H.

126 heilmannii' detected in human gastric mucosa, O'Rourke et al., 2004b). The most closely

127 related organisms were 'Candidatus H. heilmannii', H. felis, H. bizzozeronii, H. salomonis

128 and $H$. suis with a sequence similarity ranging from $93 \%$ to $98 \%$ with the novel strains.

130 Sequence analysis of the urease gene has been found to be more discriminatory than the $16 \mathrm{~S}$

131 rRNA gene for species differentiation between gastric Helicobacter species of animal origin

132 (O'Rourke et al., 2004b). Therefore, the sequences of partial fragments of the ureA and ureB

133 genes, including a spacer region, were determined after amplification using primers U430F

134 and U1735R (1224 bp amplicon) (O'Rourke et al., 2004b). The sequences were compared

135 with the NCBI genbank by using the BLAST search tool. Based on the phylogenetic tree,

136 reconstructed from genetic distances of the 16r RNA gene sequences, the most closely related

137 Helicobacter species were included for phylogenetic analysis of the ureaAB gene.

138 Phylogenetic analysis was performed using the same software tools as described for the $16 \mathrm{~S}$

139 rRNA gene. A phylogenetic tree, with $H$. pylori as outgroup, was constructed using the

140 neighbour-joining method and is shown in Fig. 2.

141 Isolates ASB1 ${ }^{\mathrm{T}}$, ASB2 and ASB3 showed 98\% similarity with each other (Genbank accession

142 no. HM625826, HM625825, HM625824) and 91\% similarity with ureaAB gene sequences

143 from the 'Candidatus H. heilmannii' strains, detected in human and wild feline gastric

144 mucosa and previously deposited in Genbank (O'Rourke et al., 2004b). Moreover, these 3

145 isolates clustered with the 'Candidatus H. heilmannii' (Fig. 2). The phylogenetic neighbours

146 were the following species: H. bizzozeronii (about 84\% similarity), H. suis (about 82\%

147 similarity), H. felis (about 76\% similarity), H. cynogastricus (about 76\% similarity) and $H$.

148 salomonis (about $75 \%$ similarity). 
149 Mikkonen et al. (2004) showed that conserved partial $60 \mathrm{kDa}$ heat-shock protein (HSP60)

150 gene sequences give additional phylogenetic information that is useful for differentiating

151 Helicobacter species. The hsp60 gene sequences of the 'Candidatus H. heilmannii' strains

152 described by O'Rourke et al. (2004b) are not available from Genbank. A 550 bp sequence

153 was obtained for ASB $1^{\mathrm{T}}$, ASB2 and ASB3 using the methodology as described by Mikkonen

154 et al. (2004). The sequences were compared with the NCBI genbank by using the BLAST

155 search tool. Based on the phylogenetic tree, reconstructed from genetic distances of the 16r

156 RNA gene sequences, the most closely related Helicobacter species were included for

157 phylogenetic analysis of the $h s p 60$ gene. Phylogenetic analysis was performed using the same

158 software tools as described for the $16 \mathrm{~S}$ rRNA gene. A phylogenetic tree, with $H$. pylori as

159 outgroup, was constructed using the neighbour-joining method and is shown in Fig. 3. The

160 partial hsp60 gene sequences of $\mathrm{ASB} 1^{\mathrm{T}}, \mathrm{ASB} 2$ and ASB3 showed approximately 95\%

161 sequence similarity with each other (Genbank accession no. HM625823, HM625822,

162 HM625821). Gene sequence similarities of $85-86 \%, 84-86 \%, 84 \%, 84 \%, 83 \%$ and $81 \%$ were

163 obtained for $H$. felis, H. bizzozeronii, H. salomonis, $H$. cynogastricus, $H$. baculiformis and $H$.

164 suis, respectively, yielding sufficient difference to consign isolates ASB1 ${ }^{\mathrm{T}}$, ASB2 and ASB3

165 into a new taxon.

166

167 Polyacrylamide gel electrophoresis (PAGE) of whole cell proteins of strain ASB1 $^{\mathrm{T}}$, ASB2

168 and ASB3 and of H. pylori, H. bizzozeronii, H. felis, H. salomonis, H. cynogastricus, $H$.

169 baculiformis and H. suis reference strains (Jalava et al., 1998, 2001; Van den Bulck et al.,

170 2006) was performed in order to establish its distinct taxonomic status with other cultured

171 species of the genus Helicobacter. For this purpose, strains were grown on Brucella agar

172 supplemented with $20 \%$ foetal calf serum, $5 \mathrm{mg} / \mathrm{l}$ amphotericin B, Campylobacter-selective

173 supplement, Vitox supplement and ca. $0.05 \% \mathrm{HCl}$ to obtain a $\mathrm{pH}$ of 5 . Plates were incubated 
at $37^{\circ} \mathrm{C}$ in a microaerobic atmosphere as described above. Whole-cell protein extracts were

175 prepared and SDS-PAGE was performed as described previously (Pot et al., 1994). Sodium

176 dodecyl sulphate PAGE and sample preparation were performed using Criterion ${ }^{\mathrm{TM}} \mathrm{XT} 12 \%$

177 (w/v acrylamide) Bis-Tris precast gels with XT MOPS denaturing running buffer according to

178 the manufacturer's instructions (BIO-RAD, Nazareth, Belgium), but without heating the

179 samples before loading. Staining was performed with Bio-Safe ${ }^{\mathrm{TM}}$ Coomassie stain, according

180 to the manufacturer's instructions (BIO-RAD).

181 Visual and numerical analysis of the protein profiles demonstrated that strains ASB $^{\mathrm{T}}$, ASB2

182 and ASB3 can be clearly distinguished from those of their closest phylogenetic neighbours

183 (Fig. S1). These differences are not limited to one or a few bands but are apparent in the entire

184 profile.

185

186 The morphology of strain ASB $1^{\mathrm{T}}$, ASB2 and ASB3 was studied by means of transmission

187 electron microscopy (TEM) as described by Houf et al. (2005) and Mast et al. (2005) (Fig. 4).

188 Isolates ASB $1^{\mathrm{T}}$, ASB2 and ASB3 presented tightly coiled spiral-shaped cells with up to nine

189 turns, that were approximately 3 to $6.5 \mu \mathrm{m}$ long and approximately 0.6 to $0.7 \mu \mathrm{m}$ wide (Fig.

190 4). The length and width were variable depending on the state of contraction. No periplasmic

191 fibrils were observed and coccoid cells predominated in older cultures. Up to 10 sheathed

192 blunt-ended flagella were found at both ends.

193 According to the recommendations of Dewhirst et al. (2000), biochemical and tolerance tests

194 were carried out. Growth of strain ASB1 ${ }^{\mathrm{T}}$, ASB2 and ASB3 was determined on Brucella agar

195 plates supplemented with $20 \%$ foetal calf serum, $5 \mathrm{mg} / \mathrm{l}$ amphotericin B, Campylobacter-

196 selective supplement, Vitox supplement and $0.05 \% \mathrm{HCl}$ to obtain a $\mathrm{pH}$ of 5 at 25,37 and

$19742^{\circ} \mathrm{C}$ under microaerobic conditions and at $37^{\circ} \mathrm{C}$ under aerobic, anaerobic and microaerobic

198 conditions. Tolerance to $1 \%$ bile, $1 \%$ glycine and $1.5 \% \mathrm{NaCl}$ was determined on Brucella 
agar plates with the same supplements as described above. Growth was also studied on BHI

200 agar, Brucella agar and Mueller-Hinton agar (Oxoid), supplemented with $20 \%$ foetal calf serum or $10 \%$ defibrinated horse blood, Vitox and Skirrow supplements, amphotericin B and $\mathrm{HCl}$ to $\mathrm{pH}$ of 5 . The plates were incubated for several days in a microaerobic atmosphere at $37^{\circ} \mathrm{C}$. Cells are also able to grow in colonies on dry agar plates.

204 The isolates were also examined for catalase activity by adding a $3 \% \mathrm{H}_{2} \mathrm{O}_{2}$ solution and 205 observing the reaction within 5s. Oxidase activity was performed with Bactident Oxidase 206 strips (Merck, Overijse, Belgium). Following characteristics were studied using the API 207 Campy identification system (BioMérieux, Marc L'Etoile, France): urease activity, reduction 208 of nitrate, esterase activity, hydrolysis of hippurate, $\gamma$-glutamyltransferase activity, reduction 209 of triphenyl-tetrazoliumchloride (TTC), alkaline phosphatase activity and pyrrolidonyl, Larginine and L-aspartate arylamidase activity. Tests were read after $24 \mathrm{~h}$ incubation at $37^{\circ} \mathrm{C}$ in an aerobic atmosphere.

212 Growth on Mueller-Hinton II agar plates supplemented with $5 \mu \mathrm{g} / \mathrm{ml}$ metronidazole and $10 \%$ 213 horse blood was also established. The results are listed in the species description below and a 214 comparison of the most important phenotypic characteristics of strains ASB1 ${ }^{\mathrm{T}}, \mathrm{ASB} 2$ and 215 ASB3 with those of other gastric species of the genus Helicobacter is shown in Table 1. The absence of alkaline phosphatase activity and several other characteristics allowed to differentiate strains ASB $1^{\mathrm{T}}$, ASB2 and ASB3 from their closest phylogenetic neighbours. In conclusion, the phylogenetic analysis of the $16 \mathrm{~S}$ rRNA, ureAB and $h s p 60$ genes and the 219 whole-cell protein electrophoresis revealed that strains ASB1 ${ }^{\mathrm{T}}$, ASB2 and ASB3 represent a 220 novel species within the phylogenetic lineage that currently consists of $H$. felis, $H$. bizzozeronii, H. salomonis, H. baculiformis, H. cynogastricus and H. suis. 
225 Helicobacter heilmannii (heil.mann'i.i. N.L. gen. n. of Heilmann, in honour of Konrad 226 Heilmann who described the first large case study of gastrospirilla infections in humans 227 (Heilmann \& Brochard, 1991)).

Cells are tightly coiled spirals with up to nine turns, that are approximately 3 to $6.5 \mu \mathrm{m}$ long 230 and approximately 0.6 to $0.7 \mu \mathrm{m}$ wide. No periplasmic fibrils were observed and coccoid cells 231 predominated in older cultures. They are motile by means of tufts of up to 10 sheathed bluntended flagellae at both ends of the cells. Cells are Gram-negative and non-sporulating.

Growth is observed on BHI agar, Brucella agar and on Mueller-Hinton agar supplemented 234 with $20 \%$ fetal calf serum or with $10 \%$ defibrinated horse blood. Cells are also able to grow in 235 colonies on dry agar plates. Grows in micro-aerophilic conditions and weakly growth is seen 236 after anaerobic incubation. Growth is detected at $37^{\circ} \mathrm{C}$, but not at 25 or $42^{\circ} \mathrm{C}$. No growth on 237 media supplemented with $1 \%$ bile, $1.5 \% \mathrm{NaCl}$ or $1 \%$ glycine. Oxidase-, catalase- and urease238 positive. Reduces TTC, nitrate and esterase and tests positive for $\gamma$-glutamyltransferase, 239 hippurate and L-arginine arylamidase. Activity of pyrrolidonyl arylamidase, L-aspartate 240 arylamidase, indoxyl acetate hydrolysis and alkaline phosphatase was not detected. Its clinical 241 significance in cats is unknown. $H$. heilmannii, as well as other gastric non- $H$. pylori 242 Helicobacter species have been associated with gastritis, gastric and duodenal ulcers and low 243 grade MALT lymphoma of the stomach in humans (Haesebrouck et al., 2009). H. heilmannii 244 has been shown to induce MALT lymphomas when propagated in mice for up to 28 months 245 (O’Rourke et al., 2004a).

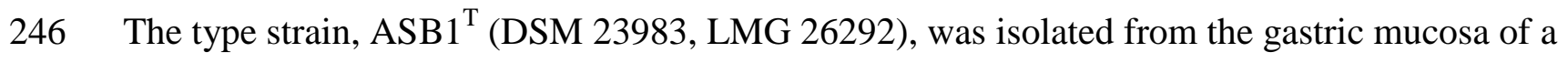
247 cat. 


\section{Nucleotide sequence accession numbers}

250 The 16S rRNA gene sequences of $H$. heilmannii ASB $1^{\mathrm{T}}$ (= type strain), ASB2 and ASB3 are 251 available from GenBank under accession number HM625820, HM625819 and HM625818, 252 respectively. The partial $u r e A B$ gene sequences of $H$. heilmannii $\mathrm{ASB} 1^{\mathrm{T}}, \mathrm{ASB} 2$ and ASB3 are 253 available from GenBank under accession number HM625826, HM625825 and HM625824, 254 respectively. The $h s p 60$ gene sequences of $H$. heilmannii $\mathrm{ASB} 1^{\mathrm{T}}$, ASB2 and ASB3 are 255 available from GenBank under accession number HM625823, HM625822 and HM625821, 256 respectively.

\section{Acknowledgements}

259 This work was supported by the Research Fund of Ghent University, Belgium, Code 260 GOA01G00408. The authors are very grateful to Sofie De Bruyckere and Dominique Jacobus 261 for their excellent technical assistance.

\section{References}

264 Baele, M., Decostere, A., Vandamme, P., Ceelen, L., Hellemans, A., Mast, J., Chiers, K., 265 Ducatelle, R. \& Haesebrouck, F. (2008a). Isolation and characterization of Helicobacter 266 suis sp. nov. from pig stomachs. Int J Syst Evol Microbiol 58, 1350-1358.

267 Baele, M., Decostere, A., Vandamme, P., Van den Bulck, K., Gruntar, I., Mehle, J., 268 Mast, J., Ducatelle, R. \& Haesebrouck, F. (2008b). Helicobacter baculiformis sp. nov., 269 isolated from the feline stomach mucosa. Int J Syst Evol Microbiol 58, 357-364.

270 Baele, M., Devriese, L. A. \& Haesebrouck, F. (2001). Lactobacillus agilis is an important 271 component of the pigeon crop flora. J Appl Microbiol 91, 488-491. 
273 Vandamme, P. (1999). Classification of Alcaligenes faecalis-like isolates from the 274 environment and human clinical samples as Ralstonia gilardii sp. nov. Int J Syst Bacteriol 49, $275 \quad 405-413$.

276 Dewhirst, F. E., Fox, J. G. \& On, S. L. W. (2000). Recommended minimal standards for 277 describing new species of the genus Helicobacter. Int J Syst Evol Microbiol 50, 2231-2237.

278 Gruntar I., Mehle, J., Krt, B., Ocepek, M., Gombac, M., Cerne, M. \& Pogacnik, M. 279 (2003). New approaches in isolation of Helicobacter spp. from gastric mucosa in dogs. Int J 280 Med Microbiol 293 (Supplement), 65.

281 Haesebrouck, F., Pasmans, F., Flahou, B., Chiers, K., Baele, M., Meyns, T., Decostere A. 282 \& Ducatelle, R. (2009). Gastric Helicobacters in domestic animals and nonhuman primates 283 and their significance for human health. Clin Microbiol Rev 22, 202-223.

284 Hänninen, M. L., Happonen, I., Saari, S. \& Jalava, K. (1996). Culture and characteristics 285 of Helicobacter bizzozeronii, a new canine gastric sp. Int J Syst Bacteriol 46, 160-166.

286 Happonen, I., Saari, S., Castren, L., Tyni, O., Hänninen, M. L. \& Westermarck E. 287 (1996). Occurrence and topographical mapping of gastric Helicobacter-like organisms and 288 their association with histological changes in apparently healthy dogs and cats. Zentbl Vet 289 Med Reiche A 43, 305-315.

290 Heilmann, K. L. \& Borchard, F. (1991). Gastritis due to spiral shaped bacteria other than 291 Helicobacter pylori: clinical, histological, and ultrastructural findings. Gut 32, 137-140.

292 Houf, K., On, S. L. W., Coenye, T., Mast, J., Van Hoof, J. \& Vandamme, P. (2005). 293 Arcobacter cibarius sp nov., isolated from broiler carcasses. Int J Syst Evol Microbiol 55, $294 \quad 713-717$. 
Hwang, C. Y., Han, H. R. \& Youn, H. Y. (2002). Prevalence and clinical characterization of gastric Helicobacter species infection in dogs and cats in Korea. J Vet Sci 3, 123-133.

Jalava, K., Kaartinen, M., Utriainen, M., Happonen, I. \& Hänninen, M. L. (1997). Helicobacter salomonis sp. nov., a canine gastric Helicobacter sp. related to Helicobacter felis and Helicobacter bizzozeronii. Int J Syst Bacteriol 47, 975-982.

300 Jalava, K., On, S.L.W., Harrington, C.S., Andersen, L.P., Hanninen, M.L. \& 301 Vandamme, P. (2001). A cultured strain of "Helicobacter heilmannii," a human gastric 302 pathogen, identified as H. bizzozeronii: Evidence for zoonotic potential of Helicobacter. 303 Emerg Infect Dis 7, 1036-1038.

Jalava, K., On, S.L.W., Vandamme, P.A.R., Happonen, I., Sukura, A. \& Hanninen, M.L. (1998). Isolation and identification of Helicobacter spp, from canine and feline gastric mucosa. Appl Environ Microbiol 64, 3998-4006.

Lee, A., Hazell, S. L., O’Rourke, J. \& Kouprach, S. (1988). Isolation of a spiral-shaped bacterium from the cat stomach. Infect Immun 56, 2843-2850.

Mast, J., Nanbru, C., Van den Berg, T. \& Meulemans, G. (2005). Ultrastructural changes of the tracheal epithelium after vaccination of day-old chickens with the La Sota strain of 311 Newcastle disease virus. Vet Pathol 42, 559-565.

312 Mikkonen, T. P., Karenlampi, R. I. \& Hänninen, M. L. (2004). Phylogenetic analysis of 313 gastric and enterohepatic Helicobacter species based on partial HSP60 gene sequences. Int J 314 Syst Evol Microbiol 54, 753-758.

315 Neiger, R., Dieterich, C., Burnens, A., Waldvogel, A., Corthesy-Theulaz, I., Halter, F., 316 Lauterburg, B. \& Schassmann A. (1998). Detection and prevalence of Helicobacter 317 infections in pet cats. J Clin Microbiol 36, 634-637. 
O’Rourke, J. L., Dixon, M. F., Jack, A., Enno, A. \& Lee, A. (2004a). Gastric B-cell mucosa associated lympoid tissue (MALT) lymphoma in an animal model of 'Helicobacter heilmannii' infection. J Pathol 203, 896-903.

O’Rourke, J. L., Solnick, J. V., Neilan, B. A., Seidel, K., Hayter, R., Hansen, L. M. \&

Lee, A. (2004b). Description of 'Candidatus Helicobacter heilmannii' based on DNA sequence analysis of 16s rRNA and urease genes. Int J Syst Evol Microbiol 54, 2203-2211.

Pot, B., Devriese, L. A., Hommez, J., Miry, C., Vandemeulebroecke, K., Kersters, K. \&

Haesebrouck, F. (1994). Characterization and identification of Vagococcus fluvialis strains isolated from domestic animals. J Appl Bacteriol 77, 362-369.

Solnick, J. V., O’ Rourke, J., Lee, A., Paster, B. J., Dewhirst, F. E. \& Tompkins, L. S. (1993). An uncultured gastric spiral organism is a newly identified Helicobacter in humans. $J$ Infect Dis 168, 379-385.

Trebesius, K., Adler, K., Vieth, M., Stolte, M. \& Haas, R. (2001). Specific detection and prevalence of Helicobacter heilmannii-like organisms in the human gastric mucosa by fluorescent in situ hybridisation and partial 16S ribosomal DNA sequencing. J Clin Microbiol 39, 1510-1516.

Van den Bulck, K., Decostere, A., Baele, M., Driessen, A., Debognie, J. C., Burette, A.,

Stolte, M., Ducatelle R. \& Haesebrouck F. (2005). Identification of non-Helicobacter pylori spiral organisms in gastric samples of humans, dogs and cats. J Clin Microbiol 43, 22562260.

338 Van den Bulck, K., Decostere, A., Baele, M., Vandamme, P., Mast, J., Ducatelle, R. \& 339 Haesebrouck, F. (2006). Helicobacter cynogastricus sp. nov., isolated from the canine 340 gastric mucosa. Int J Syst Microbiol 56, 1559-1564. 
341 Table 1. Differential characteristics of strains ASB1 ${ }^{\mathrm{T}}$, ASB2 and ASB3 and other species of the genus Helicobacter. Urease activity was

342 uniformly present; growth in the presence of $1 \%$ glycine was uniformly absent.

\begin{tabular}{|c|c|c|c|c|c|c|c|c|}
\hline Characteristics & $\begin{array}{l}\text { H. heilmannii } \\
\text { sp. nov. }\end{array}$ & H. suis ${ }^{\#}$ & $\begin{array}{c}\mathrm{H} . \\
\text { baculiformis }^{\S}\end{array}$ & $\begin{array}{c}\boldsymbol{H} . \\
\text { cynogastricus }^{\dagger}\end{array}$ & $\begin{array}{c}\text { H. } \\
\text { bizzozeronii }^{*}\end{array}$ & 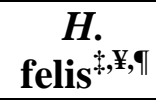 & $\begin{array}{c}\mathrm{H} . \\
\text { salomonis }^{\text {II }} \\
\end{array}$ & $\begin{array}{c}\mathrm{H} . \\
\text { pylori } \\
\end{array}$ \\
\hline Cell length $(\mu \mathrm{m})$ & $3-6.5$ & $2.3-6.7$ & 10 & $10-18$ & $5-10$ & $5-7.5$ & $5-7$ & $2.5-5$ \\
\hline Nitrate reduction & + & - & + & + & + & + & + & - \\
\hline $\begin{array}{l}\text { Alkaline phosphatase } \\
\text { activity }\end{array}$ & - & + & + & + & + & + & + & + \\
\hline \multicolumn{9}{|l|}{ Growth on/at: } \\
\hline $42^{\circ} \mathrm{C}$ & - & - & - & - & + & - & - & - \\
\hline Periplasmic fibril & - & - & + & + & - & + & - & - \\
\hline No. of flagella per cell & $4-10$ & $4-10$ & 11 & $6-12$ & $10-20$ & $14-20$ & $10-23$ & $4-8$ \\
\hline
\end{tabular}

343 BP, bipolar; MP, monopolar; ${ }^{\#}$ Baele et al. $(2008 \mathrm{a}) ;{ }^{\S}$ Baele et al. (2008b); ${ }^{\dagger}$ Van den Bulck et al. (2006); ${ }^{\ddagger}$ Hänninen et al. (1996); ${ }^{\sharp}$ Lee et al.

344 (1988); "IJalava et al. (1997) 


\section{Figure legends}

346 Fig. 1. A phylogenetic tree, reconstructed from genetic distances, based on 16S rRNA gene 347 sequences for the $H$. heilmannii sp. and other Helicobacter species. The numbers by the 348 branches indicate the number of times out of 100 that the clade was recovered by bootstrap 349 resampling (number of bootstraps: 100).

351 Fig. 2. A phylogenetic tree, reconstructed from genetic distances, based on the partial ureA 352 and $u r e B$ gene sequences for the $H$. heilmannii sp. and other urease-positive gastric Helicobacter species. Bootstrap values are indicated.

Fig. 3. A phylogenetic tree, reconstructed from genetic distances, based on the partial hsp60 gene sequences for the H. heilmannii sp. and other gastric Helicobacter species. Bootstrap values are indicated.

Fig. 4. TEM images of cells of $H$. heilmannii strain ASB $1^{\mathrm{T}}$. a, negatively stained cell of strain $\mathrm{ASB} 1^{\mathrm{T}}$; b, negatively stained cell of strain $\mathrm{ASB} 1^{\mathrm{T}}$ showing bipolar flagellae; c, TEM image of strain $\mathrm{ASB}^{\mathrm{T}}$ showing an unusual long cell with up to 9 turns; d, negatively stained cell of strain $\mathrm{ASB} 1^{\mathrm{T}}$ with blunt-ended flagellae; e, TEM image of strain ASB $1^{\mathrm{T}}$ showing a cross section of the flagellae (arrow); f, negatively stained cell of strain ASB $1^{\mathrm{T}}$ showing sheated flagellae. Bars: a, $2 \mu \mathrm{m}$; b, c and f, $1 \mu \mathrm{m} ; \mathrm{d}, 500 \mathrm{~nm}$; e, 200nm.

Fig. S1. Dendrogram derived from the numerical analysis of the whole cell protein profiles of strains $\mathrm{ASB} 1^{\mathrm{T}}, \mathrm{ASB} 2$ and $\mathrm{ASB} 3$ and gastric Helicobacter reference strains. The asterisk indicates the pattern obtained after growth of the strain on Brucella agar supplemented with $20 \%$ fetal calf serum. 
Fig. 1

371

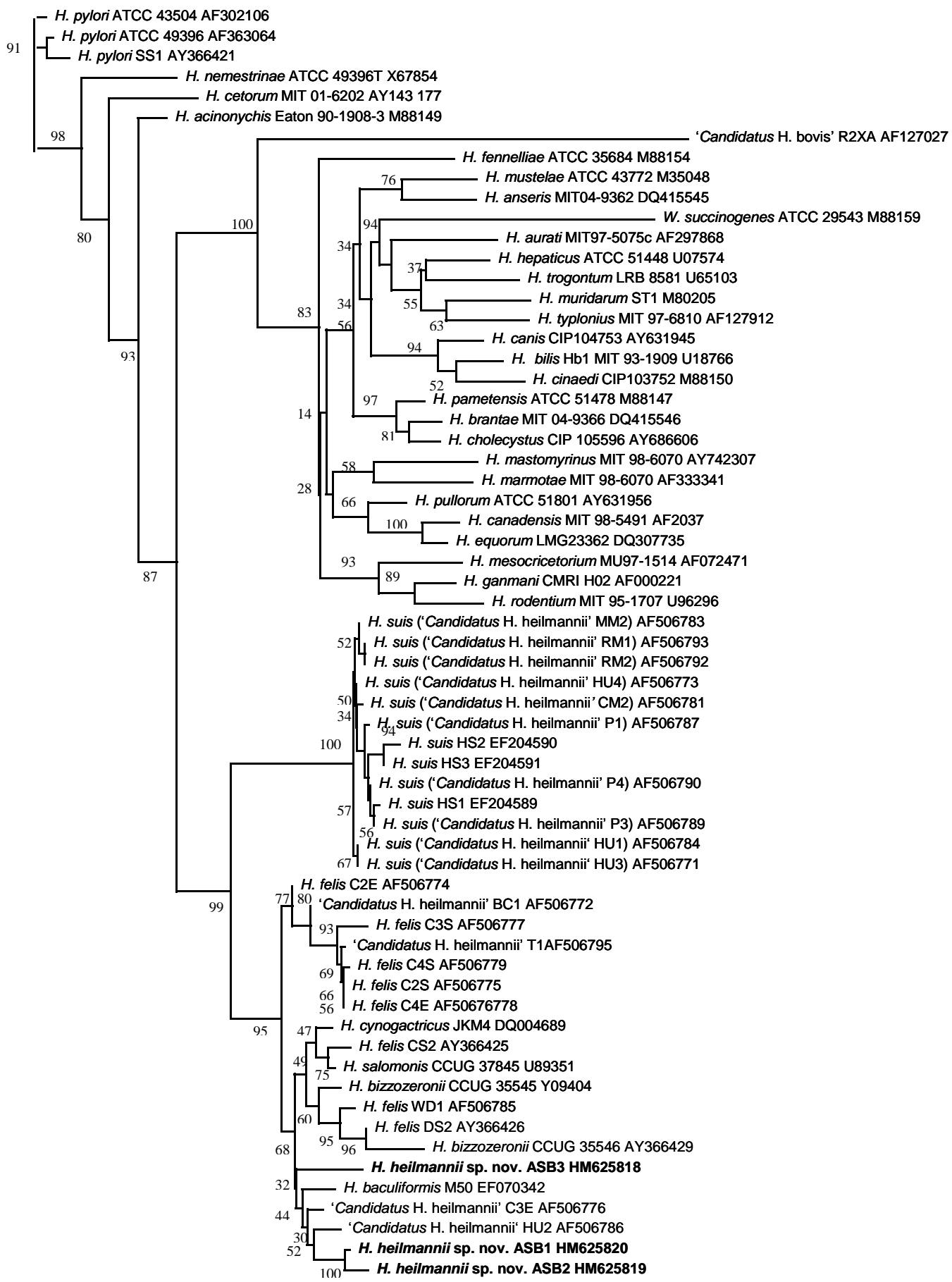




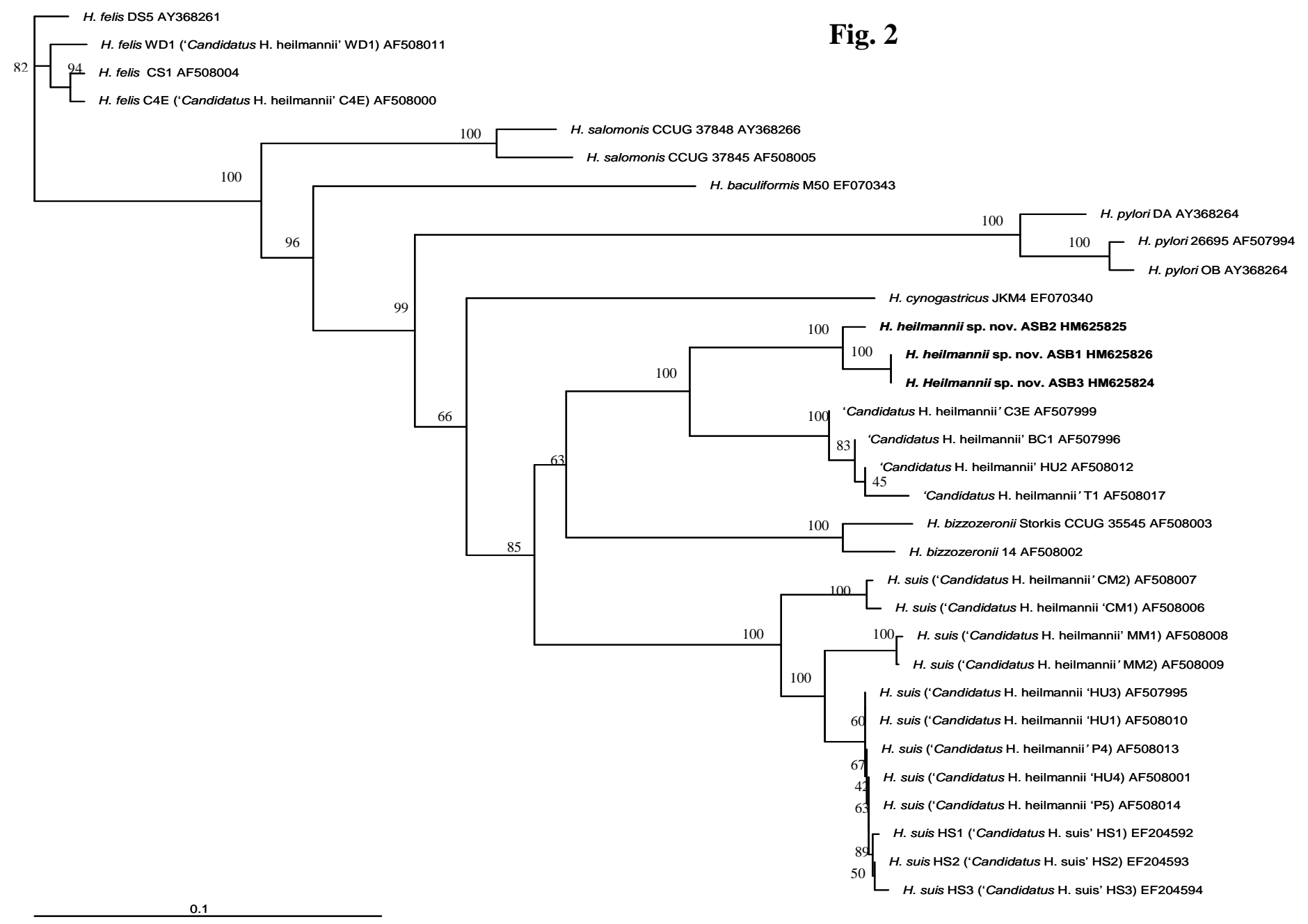


Fig. 3

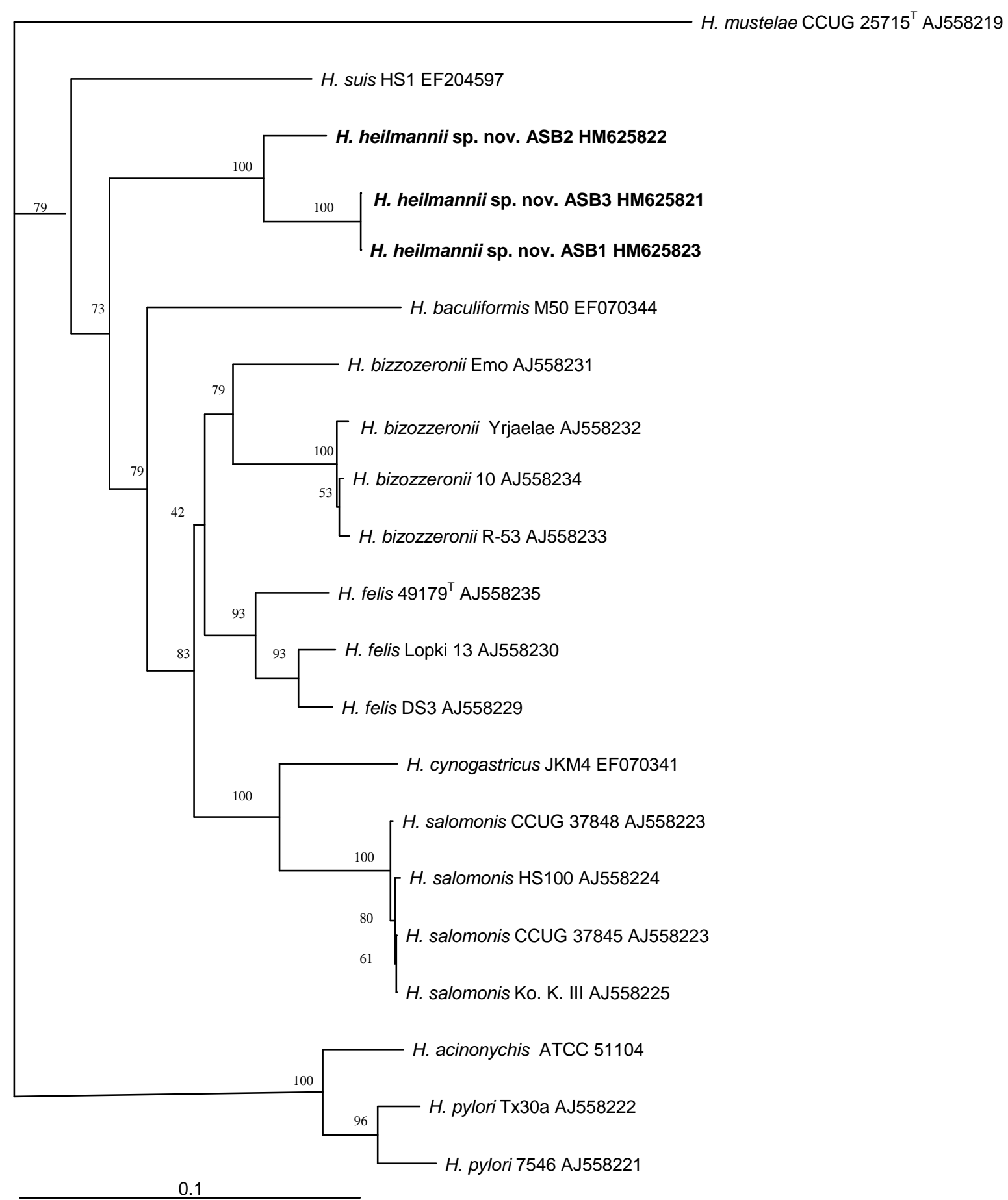

